\title{
Female role portrayals in Brazilian advertising: Are outdated cultural stereotypes preventing change?
}

\author{
Authors \\ Karen Middleton (corresponding author) \\ Portsmouth Business School, University of Portsmouth \\ Winston Churchill Ave, Portsmouth PO1 2UP. UK \\ Email karen.middleton@port.ac.uk
}

Dr Sarah Turnbull

Portsmouth Business School, University of Portsmouth

Winston Churchill Ave, Portsmouth PO1 2UP. UK

Dr Mauro José de Oliveira

Centro Universitário da FEI

Rua Tamandaré, 688

01525-000 - Liberdade, São Paulo, Brazil 


\section{Abstract}

The use of female stereotypes in advertising is damaging to women and society. In this study we examine how creative practitioners construct stereotypes within creative decision-making. In an era of brand social responsibility, it is important that advertising supports gender equality by using positive portrayals rather than harmful stereotypes. Hence, identifying and reporting on stereotyping that is negative is important to effect change in advertising practices. The study considers the influence of local cultural norms on stereotypes and finds that in Brazil, traditional conceptions of the role of women dominate creative decision-making. Through qualitative semi-structured interviews with advertising creative practitioners in Brazil, the research reveals their mental models of female stereotypes. Six distinct female stereotypes are elucidated: Housewife, Trophy, Sexual Object, Sexually Powerful, Professional and Object of Beauty. These stereotypes shape how females are depicted in Brazilian advertising. The identification of Trophy and Sexually Powerful stereotypes are novel within the extant literature. We recommend Brazilian creative practitioners seek to connect better with their female audiences in the future by representing them more equitably. However, this will require the support of advertising agency leaders to deliver training programmes that will eliminate practitioners' inherent biases.

\section{Introduction}

Gender portrayal in advertising has received significant attention in the academic literature for four decades (e.g. Goffman 1979; Furnham and Mak 1999; Wolin 2003; Eisend 2010; Wirtz, Sparks and Zimbres 2017). However, it is only in recent years that the debate has 
reached the advertising industry where complaint about the extent of traditional female role stereotyping, and its harmful effects, at both a societal and individual level, is being heard around the world (Association of National Advertisers 2016; World Federation of Advertisers 2018).

Outdated stereotypes and social norms are having a negative impact on women's careers and personal lives, and gender representation in advertising is preventing change (UN Women 2019). Advertising that features narrowly-defined depictions of gender plays a role in the social construction of gender identity, and has the potential to cause harm through restriction of people's choices, aspirations and opportunities. This includes roles, behaviours or locations which are routinely, or exclusively, associated with a particular gender, for example, women as responsible for domestic tasks. Additionally, portrayals which feature objectification, inappropriate sexualisation and unhealthily thin or unattainable body images are likewise, criticised. Indeed, advertisements that include any stereotyped depictions of gender are seen as having the potential to cause harm and widespread offence (Advertising Standards Authority 2018).

As a response to concerns, along with a consumer drive for more ethical behaviour from businesses, there is rising enthusiasm for advertising which portrays women in more equitable and empowered ways (Baxter, Kulczynski and Ilicic 2016; Chu, Lee, and Kim 2016; Åkestam, Rosengren and Dahlen 2017; Champlin et al. 2019; Royle 2019). 'Gender-positive' advertising makes ood business sense, with audiences having favourable responses to brands that promote gender equality and empowerment (Association of National Advertisers 2017; Facebook Business 2017; Unstereotype Alliance 2018). In recent years, there have been notable examples of successful, break-through campaigns, which challenge female stereotypes (for example, 
Sport England's This Girl Can, 2016; Ariel India's \#ShareTheLoad, 2016; and State Street Global Advisors' Fearless Girl, 2017); however, the use of gender stereotypes in advertising still remains entrenched and deep-rooted in practice (Windels 2016; Kantar 2018). Indeed, while $76 \%$ of female marketers and $88 \%$ of male marketers, globally, believe they avoid using gender stereotypes, almost half of consumers (both male and female) feel unrepresented by advertising (Kantar 2018). The mismatch is even further pronounced in Brazil. In a United Nations' Unstereotype Alliance survey, $81 \%$ of Brazilian women said they would like to see people like them better represented in the media and advertising, with the figure rising to $92 \%$ for black women (Unstereotype Alliance 2018).

Brazil is an important research context to consider (Taylor 2012). It has the largest advertising market in Latin America, with total advertising spend at \$15.5 million in 2018, which was more than Argentina and Mexico combined (WARC 2018). However, there is a paucity of research that specifically examines gender role portrayals in advertising in the country (Acevedo et al. 2006; Nelson and Paek 2008; Fastoso, and Whitelock 2011; Lahiri 2011). It is thought to be a society structured by patriarchy and sexism (Goncalves and Lapa, 2008; Tiburi, 2014). In general, the traditions of Iberian culture, as well as dominant Roman Catholic religious conventions, hold women subordinate to men in familial and community relationships (Teles and Bracale-Howard 2006). Women in Brazil continue to live with significant gender inequality, which is most considerable in the rural areas of the Northeast (Caulfield and Schettini 2017; Wilson Centre 2017). There have been some improvements in protecting legal and political rights of women in recent times, in some part due to an effective women's movement, but discrepancies in paid salaries, and take up of political positions remain (Fernandes, 2012). Beyond social structures, high levels of esteem for the beautiful female form, sexuality and nudity, are seen as components of Brazilian identity (Freyre 1933; 
Bocayuva 2001; Parker 2009; Edmonds 2009; Jarrin 2015) and contribute to the domination of sexism in the cultural sphere (Glick et al. 2002).

The purpose of this paper is to understand Brazilian creative practitioners' rationale for the use of female role stereotypes within the gendered, cultural environment. It uses the lens of mental models theory to identify the way in which professionals' knowledge is constructed. In doing so, it aims to establish theoretical grounding of the drivers for their continued use in Brazilian advertising portrayals. It is hoped that in understanding the reasons behind their use, we will be better able to consider how to reduce them; therefore creating more representative depictions in the future.

The authors propose the following research question: What are Brazilian advertising creative practitioners' mental models of female role stereotypes in advertising portrayals?

\section{Gender stereotypes in advertising}

A stereotype is a widely held, but fixed and oversimplified image or idea of a particular type of person, social category or behaviour. Deaux and Lewis (1984) identify four different independent dimensions relating to gender: trait descriptors (e.g. competitiveness, empathy), physical characteristics (e.g. type of clothing, muscular physique), role behaviours (e.g. expert, taking care of children), and occupational status (e.g. car mechanic, nurse). Each dimension has a masculine and a feminine version, with dimensions significantly more strongly associated

with males and females, respectively. While stereotypes can lead to false judgements and prohibit the natural expression of individuals, they are also a normal cognitive process, 
providing a means of simplification and systemization of information for more efficient sensemaking (Greenwald and Banaji 1995).

Gender role stereotypes are commonly used in advertising. As a method of simplifying communication in short timeframes, instantly recognizable 'ritual displays' of gender are a resource commonly used by advertisers (Jhally 2014; Windels 2016). Stereotypes are often seen as a 'safe solution' by advertising creative practitioners who perceive them as general knowledge that the majority of consumers would readily identify with. They prevent distraction, encouraging focus on the brand message rather than the scene or social representations themselves, averting further rational thinking on the part of consumers. Instead they lead consumers to heightened emotional reactions, particularly as they often see the stereotype as their ideal selves (Windels 2016). Further, advertising practitioners vary in the extent to which they recognize that gendered images can negatively impact audiences. While some express concern about the use of stereotyped images in advertising; external pressures, for example from clients and media agents, as well as professional cultural norms, often impede any radical changes to their practice of using them (Tuncay Zayer and Coleman 2015).

Studies suggest that homemaker/ housewife, sexual object, professional/ career-oriented and decorative/ object of beauty are the key female role stereotypes used in advertising (e.g. Dallmann 2001; Nassif and Gunter 2008; Paek, Nelson and Vilela 2011; Matthes, Prieler and Adam 2016). As gender stereotyping in advertising has decreased over the years by a small degree, alongside changing role developments in society (Eisend 2010), is it pertinent to consider the recent research here. Table 1 shows a selection of studies since 2000 as illustration. [Table 1 near here.] 


\section{Advertising creative practitioners' mental models}

Calls for advertising practitioners' perspectives point to their ability to provide a richer and more complete understanding of managerial practice (e.g. Hackley 2003; Grau and Zotos 2016). Such understanding is important because advertising professionals hold theories about advertising which differ from those gained from consumer perspectives or analysis of the content of advertising itself (Sasser and Koslow 2008; Nyilasy, Canniford and Kreshel 2013). Creative practitioners are influenced by their own cultural knowledge, which drives their creative and strategic work (Kelly, Lawlor and O'Donohoe 2005). They co-construct brand and advertising meaning with consumers and develop rational ideas about why consumers behave as they do (Belk 2017). Advertising practitioners see themselves as cognisant of consumers' affective responses toward advertising; the nature of the connection between advertising and the brand advertised; and consumer involvement with the advertising message (Kover 1995).

An individual's mental model, is 'a concentrated, personally constructed, internal conception, of external phenomena (historical, existing or projected), or experience, that affects how a person acts' (Rook 2013, 42). Inherent within this definition is the idea that conceptions, which are personally built, are matched with realities of the world, and that these conceptions exist specifically inside the mind of an individual. Small-scale models of external reality are carried in the mind as an interpretation of something external (Mohammed, Ferzandi and Hamilton 2010). In order to capture wider cultural and societal influences, the uncovering of mental models allows study of the way advertising practitioners' knowledge is constructed, leading to an understanding of their choices within context. In utilising the concept, new theoretical perspectives can be developed through an understanding of communities of practice (Wenger 2011) and the social construction of ideas. The current paper draws upon advertising 
professionals' culturally-determined creative decision-making on appropriate gender portrayals, recognizing that these are anchored within their shared professional environment.

\section{Method}

In investigating mental models, qualitative techniques are a commonly used elicitation technique, allowing participants to develop cognitive composition in their own terminology and a richer content of verbal data than is feasible with quantitative techniques (Mohammed, Ferzandi and Hamilton 2010). Within this study, participants' statements during semistructured interviews, revealed the nature of creative work goals, performance requirements, strategies and plans. The account of these mental models highlights the creative choices practitioners make in adhering to stereotypes, affording detail on their symbolic nature. Subsequent generation of codes from the thematic analysis (Clarke and Braun 2013), including concepts and relationships between concepts, were developed by the researchers as mental models.

A purposive sample was used for the study. Using purposive sampling is seen as appropriate for studies which aim to explore phenomenon and improve understanding of complex issues, such as creatives' mental models of advertising stereotypes (Sarstedt et al. 2017). Additionally, purposive sampling allowed the researchers to create a sample that was specific to the needs of the study (Robinson 2014; Sarstedt et al. 2017). This enabled the study to include participants from three Brazilian cities; Belo Horizonte, Sao Paulo and Rio de Janeiro and to ensure male and female Art Directors, Creative Directors and Copywriters, with at least 5 years' experience of advertising agency practice in Brazil were included (see Table 2 for participant profiles) . A total of 22 creatives were interviewed, which was seen to provide a sufficient amount of data 
for trustworthy analysis (Saldaña and Omasta 2018). While the sample strategy and size limits generalizability of the results, understanding the complex nature of creatives' mental models was seen to be of greater importance (Boddy 2016). [Table 2 near here.]

Advertising creatives are difficult to access (Stuhlfaut and Windels 2012) and therefore the researchers used a snowball technique to invite participation in the study (Creswell and Poth 2018). Snowball sampling allowed the researchers to ask participants to recommend other similar participants to take part in the study and provided access to hard to reach Art Directors and Copywriters in Brazil (Saldaña and Omasta 2018).

Data saturation (Flick 2014; Boddy 2016) was deemed to have been reached after eighteeen interviews, whereby new themes identified after this point were not novel in substance, but rather were variations on existing themes already developed. The remaining four interviews were conducted as part of verifying the stability and variability of the data. Here, the rate of increase was small and diminished over time. Accordingly, the sample size of 22 respondents was judged to be appropriate and is of a similar number to that used in comparable research studies (Okazaki and Mueller 2011; Shao, Desmarais and Weaver 2014; Howe-Walsh et al. 2018).

The interviews, which lasted up to one and a half hours, were conducted in Brazilian Portuguese by a native-speaker and then transcribed verbatim. The transcripts were subsequently translated from Portuguese into English by a bilingual speaker, utilising back translation to reduce errors (Brislin 1970). 
In an attempt to be as open as possible and allow participants to guide and dictate the development of their own concepts, thoughts and interpretations, they were firstly asked the question, 'how are women portrayed in Brazilian advertising?' As the interviews progressed, they were then asked to describe different role stereotypes for women in advertising. Subsequently, their reflections were sought on the appropriate creative contexts for these stereotypes; when are they used; the significance of the stereotypes; and the reasons and rationale for their use.

A four stage thematic analysis was used to code the data, ensuring analysis was consistent and systematic (Kurasaki 2000). Firstly, an initial coding document of conceptual categories was prepared based on the research objectives and key themes from the literature (Turnbull and Wheeler 2017). Secondly, after each interview, the interviewer (third author) compiled detailed notes as reflection to guide data analysis. Thirdly, the data was matched with these categories and further categories were added from the detailed line-by-line analysis of the data. Finally, towards providing credibility and transferability (comparable internal and external validity respectively in quantitative research) of the results (Riege 2003), the most frequent and significant categories were assimilated as distinct mental models of stereotypes until data saturation was reached. In addition, in seeking to enhance intercoder reliability and therefore credibility of the findings, the advice of Seale and Silverman (1997) to seek agreement for the development of the thematic categories and their significance was followed. Namely, the authors reviewed and agreed the third and fourth stages of the data analysis process. A selection of participants' pertinent words, quoted verbatim, have been included in the findings to provide clarity in interpretation of meaning, and enhance validity. 


\section{Findings}

The study explores Brazilian advertising creative practitioners' mental models of female stereotypes in advertising. It identifies six distinct role stereotypes employed by practitioners in constructing female role portrayals in advertising. These are Housewife, Trophy, Sexual Object, Sexually Powerful, Professional and Object of Beauty.

\section{Housewife}

Mental models of domestic duties, concerning running a home and family, feature solely women taking on the responsibility. In advertising portrayals, it is women who undertake core housework tasks such as laundry, cleaning, cooking and caring for children, while men are seen to focus on paid work. Participants recognised that in some sections of Brazilian society, men are increasingly taking on the burden of domestic tasks in real life, and are the purchasers of domestic care products, for example, as bachelors or where the woman is the main breadwinner. However, there is still reluctance to corrupt the traditional female role in advertising portrayals, "you never see a man, it is always a woman as the homemaker, the wife is the person doing the housework. At this point I think it's still sexist" (P16: Male Creative Director, aged 37). Despite changes in behaviour patterns, and even criticism of traditional gender norms in society, creatives' mental models of domesticity in advertising do not include men as 'house-husbands' or even show them undertaking these kinds of tasks at all. Mental models of women in the domestic setting may extend to the aspirational 'superwoman' figure of a professional woman balancing home-life, work and family. 
She can also be a professional in the office, an executive success. She arrives home from work, fixes dinner for the family, the house is all perfect, everyone is happy (P12: Female Copywriter, aged 60).

Participants referred to the term "margarine family" as a theme common in Brazilian advertising. This is a representation of a stereotyped wholesome, typically white, successful family living by traditional family values and age hierarchies. Traditional family norms are seen as desirable, and in framing idealistic scenes of the home, both the nuclear and extended family should fit the conventional mold or else risk being shown as somehow deficient. As one male art director explained:

We represent the family in this way. There is the wife and the kids, and the husband, and the dog, the really conservative family. It's not just the woman, it's a population, an entire population stereotyped (P16: Male Creative Director, aged 37).

All practitioners expressed unwillingness to break from accepted family role portrayals, believing that this would be contrary to majority views in the country, as a male Creative Director stated, "The woman still thinks a woman's place is in the home" (P13, aged 47). A female Copywriter added, "it would take courage to do the opposite," she said, "I'd like to see any client, any large company have the courage to test that" (P12, aged 60).

\section{Trophy}

Practitioners stated that an attractive woman in an advertising text or drama can represent a status symbol for a man, where his coupling with a beautiful woman indicates his own success. 
Fundamentally, within this mental model it is the man's achievements in terms of wealth or position, rather than good-looks, that attract the sexual interest of the woman. In turn, the woman relies on physical appearance rather than personal merit, as well as doing very little of substance, other than being attractive.

Women are just used as merchandising. They are doing nothing in relation to the product. They just have good diction and a flashing smile. They do not consume that product. You just use her beauty. She is draped over him, she compliments him (P6: Male Copywriter, aged 32).

Here, in slice of life formats, a common storytelling device is to show the use of the product as leading directly to the male protagonist winning the hand, attention or approval of an attractive woman. This mental model also extends to the physically appealing female as an accessory to the male, serving to elevate his position, especially in narratives which are intended specifically to be aspirational in nature. A beautiful - invariably young - woman, on the arm of a man in an advertising narrative or image can inspire partly envious, attention from male audiences, creating an emotional engagement with the message. Informants determined the trophy stereotype as a useful motif for luxury products aimed at men. Typical examples described were automotive advertising, tailoring and watches; where a glamorous woman is often used as part of the backdrop to signify an aspirational lifestyle.

Women are represented as a symbol - a symbol of victory, and women are used in campaigns where the product is intended for men, she is inserted into a context like a prize for someone successful (P3: Male Art Director, aged 27). 


\section{Sexual object}

The encoding of women as an object of sexual desire for men was a category put forward by all the practitioners. Mental models of this stereotype include featuring female nudity; women in suggestive, revealing poses; showing protagonists in physical contact that is sexual in nature or in sexually suggestive positions; sexually explicit words, innuendo, dialogue or narrative about sex, sexual relations or conquests. In this case, the role of the sexually attractive female is to provide pleasure for men.

Practitioners were aware that sexual appeals are particularly heavily used in Brazil... I think anthropologically we are a society that likes to expose the body. There is a cultural heritage of generations of body exposure, sexuality, sensuality, and accepting it as normal. I watch some 300 commercials a day and I do not see the same exploitation of the female body in foreign advertising and I'm talking about global companies that sell to the world. (P9: Male Art Director, aged 38).

There was a consensus among practitioners in this study that a sexually appealing woman is a resource commonly used in advertising creation. They agreed that the sexual object can draw attention, building impact, salience and resonance. Some were keen to wax lyrical on the sheer magnetic allure of an attractive female body, considered a "work of art" (P14: Male Creative Director, age 44), which they determine can invoke an emotional response in male audiences, based on sexual interest. "What do 18-40 year-old men spend most time thinking about? Women. It's easy. Let's put a semi-naked woman in the ad, it will draw the attention of these guys" (P15: Male Creative Director, aged 31). For this audience, showing a sexy woman in the ad, or creating a narrative which may involve the use of the product in attracting a woman as 
an object of sexual desire, suggests excitement, fun, pleasure, hedonism. These symbolic values are then transferred to the brand. One male Art Director commented, "when we are trying to create stories or images about the high points in life, the special moments, this will often include a man having the attention of a beautiful, sexy woman" (P19, aged 27). In line with this context, participants pointed out that in advertising for beer, featuring a female sexual object is typical.

Some participants indicated cynicism about the use of sexual appeals "it must depend on the product, if there is no relevance, and there is more attention on the naked woman than the product, it becomes vulgar" (P18: Male Art Director, aged 47). Another added "sex was used to sell anything, nowadays we need to be more creative" (P4: Male Art Director, aged 34). Many of the interviewees were keen to convey this weakening of the function of the sexual object role.

I do not know why some brands do not realise that [using sexual appeals] is completely outside of what the public wants to see, society no longer accepts it. Sexual appeals were predominant, valued, but today, brands that use sexual behaviour can be criticized, not only by those who work in advertising, but by society as a whole (P2: Male Art Director, aged 30).

\section{Sexually Powerful}

Contrastingly, participants also conceptualised sexualised women as powerful; "the hot woman who has the men in hand" (P11: Male Copywriter, aged 28). Within this mental model, the woman is presented differently to the sexual object. Here, there is a subtle difference between the woman who is seen to get what she wants as a result of being sexually attractive, as opposed to solely being the object of desire or pleasure for men. Being attractive puts the woman in 
control, and she uses it as an advantage for her own benefits. As opposed to being used for the pleasure and consumption of men (as with the trophy and the sexual object), the sexually powerful woman is rewarded herself - for her own allure. She utilizes her sex appeal as an expression of her identity and as a powerful individual asset. As one practitioner commented: "In the advert with Deborah Secco [Brazilian actress] - she is highly sexual, she flirts, she says it is hot, she opens her neckline. She is using her sexual nature as a tool" (P4: Male Art Director, aged 34).

When describing this role of the powerful, sexual female, informants noted that this was a relatively recent development in the stock repertoire of advertising characters, arising from the changed position of women in society.

There is the more independent woman. She is capable. She is strong. She 'owns her own nose' [Brazilian idiom referring to the financially self-sufficient woman, who would, in theory, earn enough to pay for cosmetic surgery treatment herself, rather than relying on a husband to fund it]. She has become more confident, even more than men sometimes. Mostly, women are still used as objects, but this is something that I see has decreased, and is really changing, because of the position of women today. She is gaining her own sensuality, so she is gaining ground in advertising (P15: Male Creative Director, aged 31).

Within this mental model, the woman is conceived as sexually dynamic and forceful, rather than a passive, unintelligent sex object. She derives pleasure from her sexuality. She is not portrayed as eager to please, or simply placed with the sole purpose of gratifying men. Rather, the woman actively embraces her own sexual desire, whereas previously in advertising, the female libido may have been largely immaterial. 
Practitioners stated that this stereotype is more often used when targeting women, particularly for products that are seen to enhance attractiveness like fragrance and cosmetics.

Using beautiful women with strong sex appeal on the screen also ends up attracting a female audience, because they want to look like that female image. They think, "Oh, this woman is beautiful, has a beautiful body. If I were like her, how many men I would have at my feet?" Women want to have sex appeal. If I want to sell a perfume, I'll put a woman almost half naked with a man, [he is] beautiful and strong, lying down, and the woman in charge, doing all the talking. She thinks "Ah! This perfume, what a wonderful experience" (P7: Male Art Director, aged 30).

\section{Professional}

Interviewees stated that they increasingly determine roles for women as professionals in advertising portrayals, observing a development within their mental models of professionals; a role which in the past would have been reserved for men.

We will show women in business roles nowadays, where once it was the man who prevailed, right? She's winning a little more space in ads now, and more respect as well. The woman is having more voice, she is reaching, she is winning. So advertising is watching this, following this change coming from society (P1: Male Art Director, aged 25). 
These shifting mental models link to practitioners' ideas about women gaining status in society, where women have become more economically independent, increasingly occupying jobs where high levels of proficiency and competence are required.

However, many pointed out that in roles of paid occupation women are still typically shown in traditionally feminine lower-status jobs like teaching, nursing or in clerical roles, and it is not the norm to show women as particularly intelligent, engaged in positions of power or influence, or as knowledgeable experts. If women do appear in these latter roles, the break with the stereotype dominates the advertising message, therefore is used intentionally as a creative device to associate progressive values with the brand. Here, the disruptive impact of the portrayal of the woman as a capable professional brings salience, and women are encoded as inspirational, achieving against the odds; which serves to position the brand as ethical, responsible and aligned with social activism.

\section{Object of beauty}

Practitioners have firm ideas that women in advertising, other than where humour appeals are used, should usually be highly idealised. This corresponds with a slim physique, youthfulness and attractive facial features. This role represents a woman as decorative rather than sexualised. Female beauty is used in advertising for salience and visual appeal. Although practitioners recognised that this is a common device used in advertising, it was seen to be even more pronounced in Brazil. Overall participants voiced an "obsession” (P9: Male Art Director, aged 38) with women's beauty, the female body was described as a "cult" in Brazil (P10: Female Art Director, aged 45); physical perfection, akin to "a religious icon" (P7: Male Art Director, aged 30). 
We live seeking aesthetics, the beautiful, the famous, the perfect smile, the perfect hair colour Beauty is very important in Brazil, worshiping the beautiful is sort of a pattern in our society. If she is not beautiful the Brazilian will criticise, he won't like it and he will say so. Beauty draws attention, not ugliness, beauty sells (P8: Male Art Director, aged 30).

Many participants did refer to Dove's Campaign for Real Beauty as a highly successful advertising campaign featuring more natural, realistic versions of beauty. Nevertheless, they believed that the use of women of diverse physical appearance, age, race, shape and size could not be easily rolled out into advertising generally. Participants concurred, in Brazil beauty and attractiveness mental models are focused on European versions of female beauty, featuring pale skin and often, blonde hair and blue eyes.

Further, in Brazilian society physical attractiveness marks social status. Here, the body has compelling aesthetic value, as one participant pointed out, a well-used adage in Brazil is that "there are really no ugly people, there are only poor people" (P10: Female Art Director, aged 45). Participants observed that in Brazil personal appearance is very important for social recognition, and even social ascension.

If someone has a beautiful face, she ends up being privileged for that, more likely to do well in business. I've seen beautiful people do business more easily than others anyway (P9: Male Art Director, aged 38).

To this extent, the beautiful female need not have a notable role in a narrative drama within the ad. Indeed, it is purely the artistry or physical charm of the female form that can comprise the 
central theme. There need not always be a direct relationship or congruence between the idea of a beautiful female and the product itself being advertised.

We use beautiful women in a creative way but the image of a beautiful woman means I do not need to be creative - I'm just thinking of aesthetics! (P13: Male Creative Director, aged 47.)

\section{Discussion}

This research extends our understanding of stereotyped female portrayals used in advertising. It makes two main contributions to the literature. Firstly, it introduces two new stereotypes: 'trophy' and 'sexually powerful'; which were previously considered within the 'sexual object' role in extant studies on female role stereotypes (e.g. Furnham and Mak 1999; Lysonski 1985; Matthes, Prieler and Adam 2016). Secondly, in terms of managerial significance for international and global firms, the study provides data drawn from the under-researched market of Brazil. In doing so, it provides an understanding of the impact of the distinctive local cultural environment upon portrayals of women in advertising.

\section{Two new stereotypes - trophy and sexually powerful}

The practitioners in this study determined distinct functions for these additional stereotypes, seeing subtle differentiation in cultural meaning. In advertising, the prevalence of sexual appeals is well recognised (Choi et al. 2016; Samson 2016; Wirtz, Sparks, and Zimbres 2017). However, practitioners identified more narrow tropes within the role of the sexual female than simply viewing her as an object. The key differences between the sexually powerful woman, the sexual object and the trophy are discussed here. 
The trophy stereotype features the woman as an accessory for a man. This differs from the sexual object, which is merely a disposable object of the male gaze. The trophy's status is elevated in comparison - but only to a small degree - by virtue of her association or possession by a powerful, successful man. In this characterisation, the man retains domination over the woman, and her status is only borrowed via her partnership with him. He provides her with power and material wealth, and in return, he enjoys her ornamental value and sex appeal. In this sense, the trophy lacks her own independence and voice; rather she is a reward for a man's weightier achievements in life.

The sexually powerful stereotype, however, carries her own influence with the use of her erotic capital (Hakim 2011). She may be commanding or superior to men, who may themselves, be shown at her mercy, entirely distracted and hypnotised, doing her bidding in order to be in favour. Sexual appeal carries value as a personal asset for both men and women, but in general women work harder at it, and gain more advantages from it (Webster and Driskell 1983, Blanchflower and Oswald 2004). Practitioners recognise this dynamic in constructions of this stereotype. Advertising storylines and images may feature this character as a sexual dominatrix, where 'sex sells' with a contemporary twist, in favour of a new-found female sexual confidence.

This represents a contrast with the sexual object stereotype. The sexual object's body, body parts or sexual functions are the focus of the portrayal and are separated from her as a person. The woman's features are reduced to instruments and are regarded as representing her (Fredrickson and Roberts 1997). As distinct from the sexually powerful stereotype, the sexual object role carries a negatively valanced or inferior status. As sexual objects, women are 
perceived as marginalised by constant visual evaluation of their bodies the media and advertising as simple vessels for the pleasure, gaze and use of others (Boddewyn 1991; Kilbourne 1994; Moradi and Yu-Ping Huang 2008).

\section{Brazilian cultural context}

Given that Brazilians easily recognize sexual nuances, and are able to assign relatively straightforward meanings to a repertoire of possible sexual relationships and dynamics (Parker 2009), it is not surprising that the creatives interviewed in the current study were able to clearly articulate the six distinct female gender role stereotypes. There are highly distinct frames of reference around sexuality, masculinity and femininity, which are very familiar aspects of Brazilian culture. This cultural literacy in matters of sexuality, eroticism and gender hierarchy may explain why a study within this national context has only now brought these narrow role stereotypes to light, despite the fact that they may also exist in differing cultural settings. However, further empirical investigation would be required to confirm this is the case.

The study contributes to our understanding of the impact of nuanced regional or national culture-specific effects upon portrayals of women in advertising (Petrovici and Paliwoda 2007; Maslowska et al. 2013). Practitioners alluded to the popular notion in Brazil that everyone has a 'right to beauty', where attractiveness can transcend other sources of social ranking (Parker 2009). They reflected upon the Brazilian cultural idea that looks are a currency that can be used like any other (Jarrin 2012). This culture-specific discourse on the ascendancy of beauty, is derived from complex, social and historical influences, or in Nyilasy, Canniford, and Kreshel's (2013) terminology, social iterative forces, which in turn, influence advertising content. These forces would explain contradictory findings in levels of appropriate and gender role depiction, 
including sexualized content, in advertising from different countries (Milner and Collins 2000; Nelson and Paek 2008, Matthes, Prieler and Adam 2016), when cultural values measures (e.g. Hofstede 1984) and stage of economic development are similar (Manceau and TissierDesbordes 2006).

\section{Conclusions and managerial implications}

This study considered the complex and nuanced cultural particularities that influence practitioners' creative decisions in relation to female role portrayals, revealing their perceptions of the role and function of such stereotypes in advertising. Although, practitioners believed there were some creative contexts where the subversion of traditional stereotypes was appropriate, overall this study provides evidence that the use of traditional female stereotypes in advertising remains entrenched in Brazil.

In an era when advertisers in markets around the globe are intensifying efforts to ensure that advertising is appropriate and respectful, it appears that, the contrary is the case in Brazil, where for the majority of Brazilian creative practitioners maintaining the status quo is the easier route to take. Gender developments in society have changed both the nature of consumer markets, and audience expectations of gender representation in advertising images, and there are now clear business reasons for the promotion of gender equality and empowerment. We suggest Brazilian creative practitioners utilise this understanding to develop more connected interactions with customers in designing advertising campaigns. However, given the predominant mental models of creative practitioners identified in this study, it will take support within the industry for them to step away from the continued use of outdated gender role stereotypes. 
It is recommended that advertising agencies in Brazil implement mandatory unconscious bias training, ensuring that staff at all levels are aware of their own gender biases. This will assist those at the creative decision-making heart of advertising agencies, firstly to understand that their use of gender stereotypes is automatic, unintentional and deeply-engrained; secondly, the harmful impact of using stereotypes; and thirdly, to challenge them to bring further creativity to their portrayals of women, which will ultimately resonate with audiences in positive ways.

\section{Limitations and future research}

While the sample utilised in the study reflects the gender imbalance in the Brazilian advertising industry (where only $10 \%$ of professionals employed in creative roles are women, Agência Pública 2015), it would be prudent for future research to engage a female-only sample of creative practitioners. It would be interesting to examine female practitioners' mental models of gender stereotypes more specifically, considering the domination of both male representation, and masculine values in advertising agencies in general (Gregory 2009; Grow, Roca and Broyles 2012; Windels and Lee 2012). With this in mind, although the study highlighted some existing creative opportunities for diversion from the use of female role stereotypes, taking into account cultural mores; the research did not directly address the professional and institutional pressures that maintain practitioners' current practice. Future research should attempt to examine in detail, the constraints upon advertising practitioners, in moving away from the sustained use of gender stereotypes.

Although the lesbian/gay/bisexual/transgender (LGBT) community has become an increasingly important part of the consumer market (Da Silva and Bezerra 2018), when asked 
to describe women's portrayals in advertising, none of the twenty-two informants mentioned them. This omission may be an inherent demonstration of the marginalisation of this group, where they are seen as having unique or 'other' status, and did not even come to mind when asked to characterise female depictions. Certainly, this exclusion on the part of participants in the current study would seem to support a claim of LGBT invisibility in advertising. There are discernible calls for both companies, and the media, to pay attention to this once largely ignored segment, not least because doing so could represent an opportunity for market growth (Burnett 2000). However, it would seem that advertisers are often reluctant to use them for similar fears of alienating consumers (Oakenfull and Greenlee 2004), as were identified in the current study. LGBT depictions would exemplify non-stereotyped gender role portrayals and future research should examine the social- and brand-related effects of their positive use in advertising in different countries.

Finally, the participants in this study affirmed that Brazilian norms of beauty favour western characteristics, and indeed, inter- and intra- colour social stratification by skin colour, beyond specific race, is indicated in estimates of inequality in the country (Bailey, Loveman and Muniz 2013; Monk 2016). Future research should attempt to bring further attention to intersectional issues in promoting more diverse, representative portrayals in advertising.

\section{References}

Acevedo, Claudia Rosa, Jouliana Jordan Nohara, Ana Laura Arruda, H. R. Da Silva Tamashiro, and T. Brashear. "How women are depicted in ads? A content analysis study with Brazilian advertisements." International Business \& Economics Research Journal (IBER) 5, no. 10 (2006): 59 . 
Advertising Standards Authority. 2018. "Tackling Harmful Gender Stereotypes in Advertising." $A S A \mid C A P$. Retrieved from: https://www.asa.org.uk/resource/tackling-harmfulgender-stereotypes-in-advertising.html.

Agência Pública. (2015). Sexisim is a house rule. Retrieved from: http://apublica.org/2015/03/machismo-e-a-regra-da-casa/.

Åkestam, Nina, Sara Rosengren, and Micael Dahlen. "Advertising "like a girl”: Toward a better understanding of "femvertising" and its effects." Psychology \& Marketing 34, no. 8 (2017): $795-806$

An, Daechun, and Sanghoon Kim. "Relating Hofstede's masculinity dimension to gender role portrayals in advertising: A cross-cultural comparison of web advertisements." International Marketing Review 24, no. 2 (2007): 181-207.

Association of National Advertisers. 2016. "\#SeeHer." Retrieved from: https://seeher.com/about

Baxter, Stacey M., Alicia Kulczynski, and Jasmina Ilicic. "Ads aimed at dads: Exploring consumers' reactions towards advertising that conforms and challenges traditional gender role ideologies." International Journal of Advertising 35, no. 6 (2016): 970-982.

Belk, Russell W. "Qualitative research in advertising." Journal of Advertising 46, no. 1 (2017): $36-47$. 
Blanchflower, David G., and Andrew J. Oswald. "Money, sex and happiness: An empirical study." The Scandinavian Journal of Economics 106, no. 3 (2004): 393-415.

Bocayuva, H. Erotismo à brasileira. Editora Garamond, 2001.

Boddewyn, Jean J. "Controlling sex and decency in advertising around the world." Journal of Advertising 20, no. 4 (1991): 25-35.

Boddy, Clive Roland. "Sample size for qualitative research." Qualitative Market Research: An International Journal 19, no. 4 (2016): 426-432.

Brislin, Richard W. "Back-translation for cross-cultural research." Journal of cross-cultural psychology 1, no. 3 (1970): 185-216.

Burnett, John J. "Gays: feelings about advertising and media used." Journal of Advertising Research 40, no. 1-2 (2000): 75-84.

Caulfield, Sueann, and Cristiana Schettini. "Gender and sexuality in Brazil since independence." In Oxford Research Encyclopedia of Latin American History. 2017.

Champlin, Sara, Yvette Sterbenk, Kasey Windels, and Maddison Poteet. "How brand-cause fit shapes real world advertising messages: a qualitative exploration of ‘femvertising'." International Journal of Advertising (2019): 1-24. 
Choi, Hojoon, Kyunga Yoo, Tom Reichert, and Michael S. LaTour. "Do feminists still respond negatively to female nudity in advertising? Investigating the influence of feminist attitudes on reactions to sexual appeals." International Journal of Advertising 35, no. 5 (2016): 823-845.

Chu, Kyounghee, Doo-Hee Lee, and Ji Yoon Kim. "The effect of non-stereotypical gender role advertising on consumer evaluation." International Journal of Advertising 35, no. 1 (2016): 106-134.

Clarke, Victoria, and Virginia Braun. "Teaching thematic analysis: Overcoming challenges and developing strategies for effective learning." The psychologist 26, no. 2 (2013): 120-123.

Creswell, John W., and Cheryl N. Poth. Qualitative inquiry and research design: Choosing among five approaches. Sage publications, 2017.

Da Silva, E. R. S., and Bezerra, J. S. (2018). LGBT representation in Brazilian advertising: a case study of Avon's skin democracy campaign. Retrieved from: http://www.editorarealize.com.br/revistas/conages/trabalhos/TRABALHO_EV112_MD1_SA 13_ID157_07052018150953.pdf

Dallmann, Katharina M. "Targeting women in German and Japanese magazine advertising: A difference-in-differences approach." European Journal of Marketing 35, no. 11/12 (2001): $1320-1341$

Das, Mallika. "Gender role portrayals in Indian television ads." Sex Roles 64, no. 3-4 (2011): 208-222. 
Deaux, Kay, and Laurie L. Lewis. "Structure of gender stereotypes: Interrelationships among components and gender label." Journal of personality and Social Psychology 46, no. 5 (1984): 991.

Döring, Nicola, and Sandra Pöschl. "Images of men and women in mobile phone advertisements: A content analysis of advertisements for mobile communication systems in selected popular magazines." Sex Roles 55, no. 3-4 (2006): 173-185.

Edmonds, Alexander. "Learning to love yourself: esthetics, health, and therapeutics in Brazilian plastic surgery." Ethnos 74, no. 4 (2009): 465-489.

Eisend, Martin. "A meta-analysis of gender roles in advertising." Journal of the Academy of Marketing Science 38, no. 4 (2010): 418-440.

Fastoso, Fernando, and Jeryl Whitelock. "Why is so little marketing research on Latin America published in high quality journals and what can we do about it? Lessons from a Delphi study of authors who have succeeded." International Marketing Review 28, no. 4 (2011): 435-449.

Fernandes, Sabrina. "Dilma Rousseff and the challenge of fighting patriarchy through political representation in Brazil." Journal of International Women's Studies 13, no. 3 (2012): 114-126.

Flick, Uwe. An introduction to qualitative research. Sage, 2014. 
Fredrickson, Barbara L., and Tomi-Ann Roberts. "Objectification theory: Toward understanding women's lived experiences and mental health risks." Psychology of women quarterly 21, no. 2 (1997): 173-206.

Freyre, Gilberto. "Casa-Grande and Senzala (Formação da Família sob o Regime de Economia Patriarcal) Rio de Janeiro." Maia \& Schmidt (1933).

Frith, Katherine, Ping Shaw, and Hong Cheng. "The construction of beauty: A cross-cultural analysis of women's magazine advertising." Journal of communication 55, no. 1 (2005): 5670.

Furnham, Adrian, and Twiggy Mak. "Sex-role stereotyping in television commercials: A review and comparison of fourteen studies done on five continents over 25 years." Sex roles 41 , no. 5-6 (1999): 413-437.

Glick, Peter, Nuray Sakalli-Ugurlu, Maria Cristina Ferreira, and Marcos Aguiar de Souza. "Ambivalent sexism and attitudes toward wife abuse in Turkey and Brazil." Psychology of Women Quarterly 26, no. 4 (2002): 292-297.

Goffman, Erving. "Gender advertisements." (1979).

Gonçalves, Tamara Amoroso, and Thaís de Souza Lapa. "Aborto e religião nos tribunais brasileiros." Coordenação de Tamara Amoroso Gonçalves. São Paulo: Instituto para a Promoção da Equidade (2008). 
Grau, Stacy Landreth, and Yorgos C. Zotos. "Gender stereotypes in advertising: a review of current research." International Journal of Advertising 35, no. 5 (2016): 761-770.

Greenwald, Anthony G., and Mahzarin R. Banaji. "Implicit social cognition: attitudes, selfesteem, and stereotypes." Psychological review 102, no. 1 (1995): 4.

Gregory, Michele Rene. "Inside the locker room: Male homosociability in the advertising industry." Gender, Work \& Organization 16, no. 3 (2009): 323-347.

Grow, Jean, David Roca, and Sheri J. Broyles. "Vanishing acts: Creative women in Spain and the United States." International Journal of Advertising 31, no. 3 (2012): 657-679.

Hackley, Christopher E. "Account planning: Current agency perspectives on an advertising enigma." Journal of advertising research 43, no. 2 (2003): 235-245.

Hakim, Catherine. Work-lifestyle choices in the 21st century: Preference theory. OUp Oxford, 2000.

Hatzithomas, Leonidas, Christina Boutsouki, and Paschalina Ziamou. "A longitudinal analysis of the changing roles of gender in advertising: a content analysis of Super Bowl commercials." International Journal of Advertising 35, no. 5 (2016): 888-906.

Hofstede, Geert. Culture's consequences: International differences in work-related values. Vol. 5. Sage, 1984. 
Howe-Walsh, Liza, Sarah Turnbull, and Pawan Budhwar. "An investigation into on-sourcing of advertising creativity in an emerging economy: the case of the United Arab Emirates." Journal of Business Research (2018).

Huang, Ying, and Dennis T. Lowry. "An analysis of nudity in Chinese magazine advertising: Examining gender, racial and brand differences." Sex Roles 66, no. 7-8 (2012): 440-452.

Jarrin, Alvaro. "Towards a Biopolitics of Beauty: Eugenics, Aesthetic Hierarchies and Plastic Surgery in Brazil." Journal of Latin American Cultural Studies 24, no. 4 (2015): 535-552.

Jhally, Sut. The codes of advertising: Fetishism and the political economy of meaning in the consumer society. Routledge, 2014.

Kelly, Aidan, Katrina Lawlor, and Stephanie O'Donohoe. "Encoding advertisements: the creative perspective." Journal of Marketing Management 21, no. 5-6 (2005): 505-528.

Kilbourne, Jean. "Still killing us softly: Advertising and the obsession with thinness." Feminist perspectives on eating disorders (1994): 395-418.

Kim, Kwangok, and Dennis T. Lowry. "Television commercials as a lagging social indicator: Gender role stereotypes in Korean television advertising." Sex roles 53, no. 11-12 (2005): 901910. 
Knoll, Silke, Martin Eisend, and Josefine Steinhagen. "Gender roles in advertising: Measuring and comparing gender stereotyping on public and private TV channels in Germany." International Journal of Advertising 30, no. 5 (2011): 867-888.

Kantar. 2019. “AdReaction - Getting Gender Right.” Retrieved from:

http://www.millwardbrown.com/Documents/Reports/getting_gender_right/default.aspx?acces $\mathrm{s}=\mathrm{yes}$

Kover, Arthur J. "Copywriters' implicit theories of communication: An exploration." Journal of Consumer Research 21, no. 4 (1995): 596-611.

Kurasaki, Karen S. "Intercoder reliability for validating conclusions drawn from open-ended interview data." Field methods 12, no. 3 (2000): 179-194.

Lahiri, Somnath. "Brazil-focused publications in leading business journals." European Business Review 23, no. 1 (2011): 23-44.

Lass, Paushali, and Susan Hart. "National cultures, values and lifestyles influencing consumers' perception towards sexual imagery in alcohol advertising: an exploratory study in the UK, Germany and Italy." Journal of Marketing Management 20, no. 5-6 (2004): 607-623.

Lysonski, Steven. "Role portrayals in British magazine advertisements." European Journal of Marketing 19, no. 7 (1985): 37-55. 
Mager, John, and James G. Helgeson. "Fifty years of advertising images: Some changing perspectives on role portrayals along with enduring consistencies." Sex Roles 64, no. 3-4 (2011): 238-252.

Manceau, Delphine, and Elisabeth Tissier-Desbordes. "Are sex and death taboos in advertising? An analysis of taboos in advertising and a survey of French consumer perceptions." International Journal of Advertising 25, no. 1 (2006): 9-33.

Maslowska, Ewa, Edith G. Smit, and Bas van den Putte. "Assessing the cross-cultural applicability of tailored advertising: a comparative study between the Netherlands and Poland." International Journal of Advertising 32, no. 4 (2013): 487-511.

Matthes, Jörg, Michael Prieler, and Karoline Adam. "Gender-role portrayals in television advertising across the globe." Sex Roles 75, no. 7-8 (2016): 314-327.

Milner, Laura M., and Bronwyn Higgs. "Gender sex-role portrayals in international television advertising over time: The Australian experience." Journal of Current Issues \& Research in Advertising 26, no. 2 (2004): 81-95.

Milner, Laura M., and James M. Collins. "Sex-role portrayals and the gender of nations." Journal of Advertising 29, no. 1 (2000): 67-79.

Mohammed, Susan, Lori Ferzandi, and Katherine Hamilton. "Metaphor no more: A 15-year review of the team mental model construct." Journal of Management 36, no. 4 (2010): 876910. 
Monk-Turner, Elizabeth, Tiffany Kouts, Kevin Parris, and Cynthia Webb. "Gender role stereotyping in advertisements on three radio stations: does musical genre make a difference?." Journal of Gender Studies 16, no. 2 (2007): 173-182.

Moradi, Bonnie, and Yu-Ping Huang. "Objectification theory and psychology of women: A decade of advances and future directions." Psychology of Women Quarterly 32, no. 4 (2008): 377-398.

Nam, Kyoungtae, Guiohk Lee, and Jang-Sun Hwang. "Gender stereotypes depicted by Western and Korean advertising models in Korean adolescent girls' magazines." Sex Roles 64, no. 3-4 (2011): 223-237.

Nassif, Atif, and Barrie Gunter. "Gender representation in television advertisements in Britain and Saudi Arabia." Sex Roles 58, no. 11-12 (2008): 752-760.

Nelson, Michelle R., and Hye-Jin Paek. "Nudity of female and male models in primetime TV advertising across seven countries." International Journal of Advertising 27, no. 5 (2008): 715 744.

Nyilasy, Gergely, Robin Canniford, and Peggy J. Kreshel. "Ad agency professionals' mental models of advertising creativity." European Journal of Marketing 47, no. 10 (2013): 16911710. 
Oakenfull, Gillian, and Timothy Greenlee. "The three rules of crossing over from gay media to mainstream media advertising: Lesbians, lesbians, lesbians." Journal of Business Research 57, no. 11 (2004): 1276-1285.

Okazaki, Shintaro, and Barbara Mueller. "The impact of the lost decade on advertising in Japan: a grounded theory approach." International Journal of Advertising 30, no. 2 (2011): 205-232.

Paek, Hye-Jin, Michelle R. Nelson, and Alexandra M. Vilela. "Examination of gender-role portrayals in television advertising across seven countries." Sex roles 64, no. 3-4 (2011): 192207.

Parker, Richard G. Bodies, pleasures, and passions: Sexual culture in contemporary Brazil. Vanderbilt University Press, 2009.

Petrovici, Dan, and Stanley Paliwoda. "An empirical examination of public attitudes towards advertising in a transitional economy." International Journal of Advertising 26, no. 2 (2007): 247-276.

Plakoyiannaki, Emmanuella, Kalliopi Mathioudaki, Pavlos Dimitratos, and Yorgos Zotos. "Images of women in online advertisements of global products: does sexism exist?." Journal of Business Ethics 83, no. 1 (2008): 101.

Plakoyiannaki, Emmanuella, and Yorgos Zotos. "Female role stereotypes in print advertising: Identifying associations with magazine and product categories." European Journal of Marketing 43, no. 11/12 (2009): 1411-1434. 
Riege, Andreas M. "Validity and reliability tests in case study research: a literature review with "hands-on" applications for each research phase." Qualitative market research: An international journal 6, no. 2 (2003): 75-86.

Robinson, Oliver C. "Sampling in interview-based qualitative research: A theoretical and practical guide." Qualitative Research in Psychology 11, no. 1 (2014): 25-41.

Rook, Laura. "Mental models: a robust definition." The Learning Organization 20, no. 1 (2013): 38-47.

Royle, Orianna Rosa. 2019. "Seven inspiring ads that smash female stereotypes." Campaign. March 8. Retrieved from: https://www.campaignlive.co.uk/article/seven-inspiring-ads-smashfemale-stereotypes/1578127?bulletin=campaign_agencies_bulletin

Saldaña, Johnny, and Matt Omasta. Qualitative research: Analyzing life. SAGE Publications, 2017.

Samson, Lelia. "The Effectiveness of Using Sexual Appeals in Advertising." Journal of Media Psychology (2016).

Sarstedt, Marko, Paul Bengart, Abdel Monim Shaltoni, and Sebastian Lehmann. "The use of sampling methods in advertising research: A gap between theory and practice." International Journal of Advertising (2017): 1-14. 
Sasser, Sheila L., and Scott Koslow. "Desperately seeking advertising creativity: Engaging an imaginative" 3Ps" research agenda." Journal of Advertising 37, no. 4 (2008): 5-20.

Seale, Clive, and David Silverman. "Ensuring rigour in qualitative research." The European Journal of Public Health7, no. 4 (1997): 379-384.

Shao, Yun, Fabrice Desmarais, and C. Kay Weaver. "Chinese advertising practitioners' conceptualisation of gender representation." International Journal of Advertising 33, no. 2 (2014): 329-350.

Stankiewicz, Julie M., and Francine Rosselli. "Women as sex objects and victims in print advertisements." Sex Roles 58, no. 7-8 (2008): 579-589.

Stuhlfaut, Mark W., and Kasey Windels. "Measuring the organisational impact on creativity: The creative code intensity scale." International Journal of Advertising 31, no. 4 (2012): 795 818.

Tan, Thomas Tsu Wee, Lee Boon Ling, and Eleanor Phua Cheay Theng. "Gender-role portrayals in Malaysian and Singaporean television commercials: An international advertising perspective." Journal of Business Research 55, no. 10 (2002): 853-861.

Tartaglia, Stefano, and Chiara Rollero. "Gender stereotyping in newspaper advertisements: A cross-cultural study." Journal of cross-cultural psychology 46, no. 8 (2015): 1103-1109. 
Taylor, Charles R. "On advertising in the BRICs and other emerging markets." International Journal of Advertising (2012): 227-230.

Teles, Maria Amélia de Almeida, and Susan Bracale-Howard. "Women's Human Rights in Brazil." Peace Review: A Journal of Social Justice 18, no. 4 (2006): 485-490.

Tiburi, M. "Aborto como Metáfora". In: M. Tiburi and M. L. Borges (eds.). Filosofia: Machismos e Feminismos. Florianópolis, EDUFSC, 2014

Tsichla, Eirini, and Yorgos Zotos. "Gender portrayals revisited: searching for explicit and implicit stereotypes in Cypriot magazine advertisements." International Journal of Advertising 35, no. 6 (2016): 983-1007.

Tuncay Zayer, Linda, and Catherine A. Coleman. "Advertising professionals' perceptions of the impact of gender portrayals on men and women: A question of ethics?" Journal of Advertising 44, no. 3 (2015): 1-12.

Turnbull, Sarah, and Colin Wheeler. "The advertising creative process: A study of UK agencies." Journal of Marketing Communications 23, no. 2 (2017): 176-194.

Wenger, Etienne. "Communities of practice: A brief introduction." (2011).

Windels, Kasey. "Stereotypical or just typical: how do US practitioners view the role and function of gender stereotypes in advertisements?." International Journal of Advertising 35, no. 5 (2016): 864-887. 
Wirtz, John G., Johnny V. Sparks, and Thais M. Zimbres. "The effect of exposure to sexual appeals in advertisements on memory, attitude, and purchase intention: a meta-analytic review." International Journal of Advertising (2017): 1-31

Wolin, Lori D. "Gender issues in advertising_An oversight synthesis of research: 19702002." Journal of advertising research 43, no. 1 (2003): 111-129.

UN Women. 2019. "I want to change the way the world looks at itself." Retrieved from: http://www.unwomen.org/en/news/stories/2019/4/speech-ed-phumzile-unstereotype-alliancesummit

Unstereotype Alliance. 2018. “Beyond Gender. The Invisible Stereotypes.” Retrieved from: https://www.unstereotypealliance.org/media/files/un $\% 20$ women/unsta/resources/unstereotype $\% 20$ alliance $\% 20$ beyond $\% 20$ gender $\%$ 20report.pdf?la=en

Uray, Nimet, and Sebnem Burnaz. "An analysis of the portrayal of gender roles in Turkish television advertisements." Sex roles 48, no. 1-2 (2003): 77-87.

Valls-Fernández, Federico, and José Manuel Martínez-Vicente. "Gender stereotypes in Spanish television commercials." Sex roles 56, no. 9-10 (2007): 691-699. 
Verhellen, Yann, Nathalie Dens, and Patrick De Pelsmacker. "A longitudinal content analysis of gender role portrayal in Belgian television advertising." Journal of Marketing Communications 22, no. 2 (2016): 170-188.

WARC "Adspend Database 2018”. Retrieved from: https://www.warc.com/data/adspend/table-builder

Webster Jr, Murray, and James E. Driskell Jr. "Beauty as status." American Journal of Sociology 89, no. 1 (1983): 140-165.

Wilson Centre. 2017. "The Current State of Gender in Brazil." Retrieved from: https://www.wilsoncenter.org/blog-post/the-current-state-gender-brazil

World Federation of Advertisers. 2018. "A Guide To Progressive Portrayals in Advertising. The Case for Unstereotyping Ads." Retrieved from: https://www.wfanet.org/app/uploads/2018/05/WFA-Gender-guide_final.pdf 
Table 1. Female role stereotypes in advertising identified in a selection of studies since 2000. Country contexts shown in brackets.

\begin{tabular}{|c|c|c|c|}
\hline Housewife & Sexual Object & $\begin{array}{c}\text { Professional/ Career- } \\
\text { oriented }\end{array}$ & $\begin{array}{c}\text { Decorative/ Object of } \\
\text { Beauty }\end{array}$ \\
\hline $\begin{array}{l}\text { Tan, Ling and Theng } 2002 \\
\text { (Malaysia and Singapore) }\end{array}$ & $\begin{array}{l}\text { Uray and Burnaz } 2003 \\
\text { (Turkey) }\end{array}$ & $\begin{array}{l}\text { Dallmann } 2001 \text { (Germany } \\
\text { and Japan) }\end{array}$ & $\begin{array}{l}\text { Frith, Shaw and Cheng } 2005 \\
\text { (Singapore, Taiwan, United } \\
\text { States) }\end{array}$ \\
\hline $\begin{array}{l}\text { Milner and Higgs } 2004 \\
\text { (Australia) }\end{array}$ & $\begin{array}{l}\text { Lass, Paushali and Hart } \\
2004 \text { (United Kingdom, } \\
\text { Germany Italy) }\end{array}$ & $\begin{array}{l}\text { Acevedo et al. } 2006 \text { (Brazil) } \\
\text { An and Kim } 2007 \text { (Korea, }\end{array}$ & Acevedo et al. 2006 (Brazil) \\
\hline $\begin{array}{l}\text { Kim and Lowry } 2005 \\
\text { (Korea) }\end{array}$ & $\begin{array}{l}\text { Frith, Shaw and Cheng } 2005 \\
\text { (Singapore, Taiwan, United }\end{array}$ & $\begin{array}{l}\text { United States) } \\
\text { Nassif and Gunter } 2008\end{array}$ & $\begin{array}{l}\text { Döring and Pöschl } 2006 \\
\text { (Germany) }\end{array}$ \\
\hline Acevedo et al. 2006 (Brazil) & States) & (Britain, Saudi Arabia) & $\begin{array}{l}\text { An and Kim } 2007 \text { (Korea, } \\
\text { United States) }\end{array}$ \\
\hline $\begin{array}{l}\text { Monk-Turner et al. } 2007 \\
\text { (United States) }\end{array}$ & Acevedo et al. 2006 (Brazil) & Das 2011 (India) & Lin 2008 (Taiwan) \\
\hline $\begin{array}{l}\text { Valls-Fernández, and } \\
\text { Martínez-Vicente } 2007 \\
\text { (Spain) }\end{array}$ & $\begin{array}{l}\text { Nelson and Paek } 2008 \\
\text { (Brazil, Canada, China, } \\
\text { Germany, South } \\
\text { Korea, Thailand, United } \\
\text { States) }\end{array}$ & $\begin{array}{l}\text { Knoll, Eisend and } \\
\text { Steinhagen } 2011 \text { (Germany) } \\
\text { Mager and Hegelson } 2011 \\
\text { (United States) }\end{array}$ & $\begin{array}{l}\text { Plakoyiannaki et al. } 2008 \\
\text { Plakoyiannaki and Zotos } \\
2009 \text { (United Kingdom) }\end{array}$ \\
\hline $\begin{array}{l}\text { Nassif and Gunter } 2008 \\
\text { (Britain, Saudi Arabia) }\end{array}$ & $\begin{array}{l}\text { Stankiewicz and Rosselli } \\
2008 \text { (United States) }\end{array}$ & $\begin{array}{l}\text { Paek, Nelson, and Vilela } \\
2011 \text { (Brazil, Canada, }\end{array}$ & $\begin{array}{l}\text { Mager and Hegelson } 2011 \\
\text { (United States) }\end{array}$ \\
\hline $\begin{array}{l}\text { Plakoyiannak1 et al. } 2008 \\
\text { (Global English-speaking) }\end{array}$ & $\begin{array}{l}\text { Plakoyiannaki and Zotos } \\
2009 \text { (United Kingdom) }\end{array}$ & $\begin{array}{l}\text { Korea, Thailand, United } \\
\text { States) }\end{array}$ & $\begin{array}{l}\text { Shao, Desmarais and } \\
\text { Weaver } 2014 \text { (China) }\end{array}$ \\
\hline $\begin{array}{l}\text { Paek, Nelson and Vilela } \\
2011 \text { (Brazil, Canada, }\end{array}$ & $\begin{array}{l}\text { Mager and Hegelson } 2011 \\
\text { (United States) }\end{array}$ & $\begin{array}{l}\text { Tartaglia and Rollero } 2015 \\
\text { (Italy, Netherlands) }\end{array}$ & $\begin{array}{l}\text { Tartaglia and Rollero } 2015 \\
\text { (Italy, Netherlands) }\end{array}$ \\
\hline $\begin{array}{l}\text { China, Germany, South } \\
\text { Korea, Thailand, United } \\
\text { States) }\end{array}$ & $\begin{array}{l}\text { Nam, Lee and Hwang } 2011 \\
\text { (Korea) }\end{array}$ & $\begin{array}{l}\text { Hatzithomas, Boutsouki, } \\
\text { and Ziamou } 2016 \text { (United } \\
\text { States) }\end{array}$ & $\begin{array}{l}\text { Hatzithomas, Boutsouki, } \\
\text { and Ziamou } 2016 \text { (United } \\
\text { States) }\end{array}$ \\
\hline $\begin{array}{l}\text { Hatzithomas, Boutsouki, } \\
\text { and Ziamou } 2016 \text { (United } \\
\text { States) }\end{array}$ & $\begin{array}{l}\text { Huang and Lowry } 2012 \\
\text { (China) } \\
\text { Shao, Desmarais and }\end{array}$ & $\begin{array}{l}\text { Tsichla and Zotos } 2016 \\
\text { (Cyprus) }\end{array}$ & $\begin{array}{l}\text { Tsichla and Zotos } 2016 \\
\text { (Cyprus) }\end{array}$ \\
\hline $\begin{array}{l}\text { Tsichla and Zotos } 2016 \\
\text { (Cyprus) }\end{array}$ & $\begin{array}{l}\text { Weaver } 2014 \text { (China) } \\
\text { Hatzithomas, Boutsouki, } \\
\text { and Ziamou } 2016 \text { (United }\end{array}$ & $\begin{array}{l}\text { Matthes, Prieler and Adam } \\
2016 \text { (Austria, Brazil, } \\
\text { China, France, Germany, } \\
\text { Japan, Netherlands, }\end{array}$ & \\
\hline $\begin{array}{l}\text { Matthes, Prieler and Adam } \\
2016 \text { (Austria, Brazil, }\end{array}$ & States) & $\begin{array}{l}\text { Romania, Slovakia, South } \\
\text { Korea, Spain, United }\end{array}$ & \\
\hline $\begin{array}{l}\text { China, France, Germany, } \\
\text { Japan, Netherlands, } \\
\text { Romania, Slovakia, South } \\
\text { Korea, Spain, United } \\
\text { Kingdom, United States) }\end{array}$ & $\begin{array}{l}\text { Tsichla and Zotos } 2016 \\
\text { (Cyprus) }\end{array}$ & $\begin{array}{l}\text { Kingdom, United States) } \\
\text { Verhellen, Dens and De } \\
\text { Pelsmacker } 2016 \text { (Belgium) }\end{array}$ & \\
\hline $\begin{array}{l}\text { Verhellen, Dens and De } \\
\text { Pelsmacker } 2016 \text { (Belgium) }\end{array}$ & & & \\
\hline
\end{tabular}


Table 2. Participant profiles

\begin{tabular}{|c|c|c|c|c|}
\hline Code & Job Title & Age & Gender & City \\
\hline $\mathrm{P} 1$ & Art Director & 25 & Male & Sao Paulo \\
\hline $\mathrm{P} 2$ & Art Director & 30 & Male & Sao Paulo \\
\hline P3 & Art Director & 27 & Male & Sao Paulo \\
\hline P4 & Art Director & 34 & Male & Belo Horizonte \\
\hline P5 & Art Director & 41 & Male & Sao Paulo \\
\hline P6 & Copywriter & 32 & Male & Sao Paulo \\
\hline P7 & Art Director & 30 & Male & Sao Paulo \\
\hline P8 & Art Director & 30 & Male & Belo Horizonte \\
\hline P9 & Art Director & 38 & Male & Belo Horizonte \\
\hline P10 & Art Director & 45 & Female & Sao Paulo \\
\hline P11 & Copywriter & 28 & Male & Belo Horizonte \\
\hline $\mathrm{P} 12$ & Copywriter & 60 & Female & Sao Paulo \\
\hline P13 & Creative Director & 47 & Male & Sao Paulo \\
\hline P14 & Creative Director & 44 & Male & Sao Paulo \\
\hline P15 & Creative Director & 31 & Male & Sao Paulo \\
\hline P16 & Creative Director & 37 & Male & Sao Paulo \\
\hline P17 & Art Director & 34 & Male & Sao Paulo \\
\hline P18 & Art Director & 47 & Male & Sao Paulo \\
\hline P19 & Art Director & 27 & Male & Rio de Janeiro \\
\hline $\mathrm{P} 20$ & Art Director & 38 & Male & Sao Paulo \\
\hline $\mathrm{P} 21$ & Art Director & 38 & Male & Rio de Janeiro \\
\hline $\mathrm{P} 22$ & Copywriter & 36 & Male & Rio de Janeiro \\
\hline
\end{tabular}

